\title{
Interpretation of the Principle of Informing Parties in Polish Administrative Proceeding - Conclusions and Postulates
}

\section{Andrzej Bisztyga \& Katarzyna Płonka-Bielenin}

\author{
Department of Law and Administration, \\ Katowice School of Economics, Poland \\ ambisz@interia.pl,dariuszbielenin@wp.pl
}

BISZTYGA Andrzej - PŁONKA-BIELENIN Katarzyna, Interpretation of the Principle of Informing Parties in Polish Administrative Proceeding - Conclusions and Postulates. International and Comparative Law Review, 2018, vol. 18, no. 1, pp. 231-239. DOI: 10.2478/iclr-2018-0034.

\begin{abstract}
Summary: The principle of informing parties in the Polish administrative procedure is specified in Article 9 of the Act of 14 June 1960, the Code of Administrative Procedure. Public administration bodies are obliged to duly and comprehensively inform the parties on the factual and legal circumstances that may affect the determination of their rights and obligations being the subject of administrative proceedings. The authorities ensure that the parties and other persons involved in the proceedings do not suffer damage due to ignorance of the law, and for this purpose they provide them with necessary explanations and instructions. In administrative proceedings, not the principle of ignorantia iuris nocet the obligation of the authority, resulting in particular from Articel 9 CAP is to inform the party about the factual and legal circumstances that may affect the determination of rights and obligations that are subject to current or potential behavior. This principle applies in particular to proceedings in the field of social assistance and proceedings in the field of family benefits, where a specific law is shaped in accordance with the activities of the party. It should be assumed that a breach the party's information rules is an intrinsic and sufficient reason for repealing the decision, even if it in accordance with substantive law.
\end{abstract}

Keywords: Interpretation, rules of informing parties, Polish administrative proceedings

\section{Introduction}

The principle of informing parties in administrative proceedings is specified in Article 9 of the Act of June 14, 1960, the Code of Administrative Procedure ${ }^{1}$ (hereinafter: CPA). Pursuant to the wording of the said article, „Public administration bodies are obliged to duly and comprehensively inform the parties about the factual and legal circumstances that may affect the determination of their rights and obligations being the subject of administrative proceedings. The authorities ensure that the parties and other persons involved in the proceedings

1 Tj. Dz.U. of 2017 Pos. 1257 with later changes

Published by Palacký University Olomouc, Czech Republic, 2018.

ISSN (print): 1213-8770; ISSN (online): 2464-6601 
do not suffer damage due to ignorance of the law, and to this end provide them with necessary explanations and instructions".

The time limits for the implementation of the obligation of public administration bodies in the field of informing parties, as a rule, have been set by the limits of administrative proceedings. This position is also confirmed by the case law, namely the verdict of the Provincial Administrative Court of 28 August 2017, in which it was assumed that „Time limits for the performance of public administration authority obligations under Article 9 CAP are generally perceived as boundaries of administrative proceedings" 2 .

According to Hanna Knysiak-Molczyk, the obligation to inform arises earlier, „at the moment of the citizen's first contact with the administration, if the latter was aware of the intent of submitting the application by the person initiating the proceedings. The official should explain that the request to initiate administrative proceedings in a particular case is pointless due to the jurisdiction of the court, the lack of the page's quality (...), etc."3 Such a view was also confirmed by the verdict of the Provincial Administrative Court of 4 June 2014, in which it was assumed that the obligation to provide information referred to in Article 9 of the CAP should continue throughout the period of settlement of subsequent payments, and thus for the time in which they are to be submitted next, payment requests for a given year, settled by an administrative decision. The interpretation of Article 9 of the CAP can not be accepted, according to which the administration authorities are obliged to provide information only on cases in which proceedings are pending, because such an obligation should cover all proceedings ${ }^{4}$.

The Court rightly accepts that the obligation to provide information referred to in Article 9 of the CAP is not to be understood as an absolute duty of informational activity of administrative bodies in all contacts with the citizen. However, this order can not be limited only to pending proceedings if the nature of a given regulation not only justifies but requires such action.

\section{The scope of the subject principle of informing parties}

The material scope of providing information on factual and legal circumstances concerns rights and obligations being the subject of administrative proceedings $s^{5}$.

2 Judgment of the Provincial Administrative Court in Gliwice of August 28, 2017, IV SA / Gl 11/17 - Legalis No. 1665514

3 KNYSIAK-MOLCZYK, Hanna. Commentary on Article 9 CAP, [in:] (ed.) H. KnysiakMolczyk, Code of Administrative Procedure. Commentary, Wyd. Wolters Kluwer, Warsaw 2015 , p. 81

4 Judgment of the Provincial Administrative Court in Gdańsk dated 4 June 2014, I SA / Gd 1573/13 - Legalis No. 953454

5 ADAMIAK, Barbara. Commentary on Article 9 CAP, [in:] B. Adamiak, J. Borkowski, Code 
De lege lata, the public administration body is obliged to provide information about the factual and legal circumstances that may affect the determination of the rights and obligations of the party to the administrative proceedings. So this is information of two kinds. First, information about facts that may affect the determination of the rights and obligations of the party or parties to the administrative proceedings. It is about events, facts that can have a law-making value. This applies to facts that may potentially affect the determination of the rights and obligations of the party. The legislator therefore indicates the significance of factual circumstances that may affect the outcome of the proceedings. Secondly, information about legal circumstances that may affect the determination of the rights and obligations of the party or parties to the administrative proceedings. The concept of "legal circumstances” is not very precise. However, it undoubtedly requires a wide shot. It is rightly accepted by Grzegorz Łaszczyca that it includes "the general validity of specific legal provisions, the content of these provisions, the grounds for considering and resolving a case that affect the scope of rights acquired from a decision (...) and affecting the type of (...) duty ( ...)"

It correctly adopts the Provincial Administrative Court in its judgment of 28 September 2017 that "The principle of the obligation of the authorities to provide factual and legal information expressed in Article 9 of the CPA does not make the application or application of the law subject to the knowledge of these provisions by citizens, and in particular the knowledge of law by parties to the administrative proceedings. Therefore, the authorities must ensure that parties to proceedings do not suffer damage due to ignorance of the law, should provide them with necessary explanations and instructions (...). Moreover, the authority is obliged to inform the party about the rights and obligations arising from the provisions of procedural law, the implementation of which will affect the outcome of the case (...)"

The judgment of the Provincial Administrative Court of 11 July 2017 is important in this respect, in which it was pointed out that under the responsibilities of the body that arise from the provisions of Article 9 of the CAP, social workers are obliged to provide the website with all necessary information regarding the legal situation in which the page was found, about the obligations and entitlements resulting from this. The court emphasized that a lack of knowledge of the regulations may lead to ineffective actions for the party, which should be prevented by the authority's obligation to provide relevant information. The body's operation

of Administrative Procedure. Comment. Ed. 15, Warsaw 2017, Legal status: 2017.06.27 Legalis

6 ŁASZCZYCA, Grzegorz. Commentary to art. 9 KPA, [in:], G. Łaszczyca, C. Martysz, A. Matan, Code of Administrative Procedure, Commentary on art. 1-103, Volume I, Edition LEX a Wolters Kluwer business, Warsaw 2010, p. 133

7 Judgment of the Provincial Administrative Court in Wrocław of 28 September 2017, III SA / Wr 400/17 - Legalis no. 1694731 
can not be limited only to providing legal information, but must also include providing appropriate guidance on how to proceed to avoid damage ${ }^{8}$.

The right to information expressed in Article 9 of the CAP, however, is not unlimited $^{9}$. As was emphasized in the case law, the provision of Article 9 of the Code of Administrative Procedure does not impose an obligation on administrative authorities to provide legal advice or advice. Also, it can not be equated with the obligation to notify the party about generally applicable, published legal acts and the obligations arising therefrom, or the consequences of not adapting specific legal provisions in force or replacing its activity by instructing in the selection of the optimal course of action. The intention of the general rules of conduct is to protect the party's rights in administrative proceedings, not to release them from any procedural activity or from taking care of their own interests. You can not transfer the effects of negligence on the administrative body, deducing the defectiveness of the decision ${ }^{10}$.

The content of the second of the information obligations (Article 9 of the CAP, second sentence) of the public administration body is to ensure that par-

8 Judgment of the Provincial Administrative Court in Gliwice of 11 July 2017. - IV SA / Gl 39/17, LEX No. 2334049

9 See. e.g. Judgment of the Supreme Administrative Court (N) of 19 March 2014, II GSK 6/13 - Legalis no. 1161240 - No obligation to inform the party in cases of granting aid to young farmers "Article 9 of the CAP does not apply in cases for granting payments, however, the obligation to inform the website has been significantly limited and refers only to those cases where the party to the proceedings has requested the necessary instructions (Article 21 paragraph 2 point 4 of the Act of 7 March 2007 on supporting rural development with European funds) Agricultural Fund for Rural Development under the Rural Development Program for the years 2007-2013 (tj. Dz.U. of 2013, item 173, as amended)".

10 Judgment of the Supreme Administrative Court (N) of 30 June 2015. - II OSK 2880/13, Legalis no. 1394420; See. See also Judgment of the Supreme Administrative Court (N) of 25 February 2014, II OSK 2291/12 - Legalis No. 787985 „It is unfounded that in the event of failure to appeal the administrative authority conducting an administrative procedure, it is obliged to inform the party about the possibility of submitting, regulated in Article 58 of the CAP, the application for reinstatement of the deadline for filing an appeal, and abandoning this obligation makes it impossible to issue a decision on finding the time limit. In $\mathrm{KPA}$, there is no provision that would impose on the administration body an obligation to inform the parties about the possibility of submitting an application for reinstatement of the time limit if the appeal was filed against the deadline. The obligation to instruct about the mode of submitting the application for reinstating the deadline can not be considered necessary if the party does not ask the authority to provide information in this respect, because the authority in this situation has no grounds for assuming that the explanation is a necessary explanation referred to in Article 9 of the CAP. The obligation specified in Article 9 of the CAP is to be specified in the provisions obliging the authority to inform the party about the means of challenging decisions issued in the course of the proceedings. As regards the remaining legal means available to the party, the obligation to inform about these measures may be recognized, but at the request of the party, otherwise the authority would be obliged to provide unlimited legal assistance in the course of proceedings to the party (...)". 
ties and other persons involved in the proceedings do not suffer damage due to ignorance of the law, and for this purpose, provide them with necessary explanations and instructions.

According to the verdict of the Court of Appeal of 9 July 2014, „An application initiating administrative proceedings, in case of doubts as to the content of the request, constitutes the basis for the body to make arrangements in the scope of the actual will of the person from whom it comes. This proceeding is accompanied by due and full information to the party about the factual and legal circumstances that may affect the determination of its rights and obligations being the subject of the proceedings, and the accurate determination of the facts is also the determination of the content of the party's request. Moreover: depending on the circumstances of the case, in a situation where the party's letter does not contain an explicit application for a specific legal provision, the public administration body having regard to the legitimate interest of the party, ensuring that it does not suffer damage due to ignorance of the law, should consider all possible measures, which allow for legal provisions, and which could be used for proper settlement of the case, including the possibility of using the party's request to specify his demand. And further - the administration should take into account the intent of the page, not the literal content of provision, if it would serve the legitimate interest of the citizen"11.

W. Taras rightly states that "no one can bear negative consequences because of basing his actions on official information, while negative consequences for the citizen resulting from unreliable information should be eliminated by the administration on his own initiative"12.

The general principle of the obligation of public administration bodies to provide factual and legal information is of fundamental importance for shaping the administration-unit relationship. Administrative authorities can not use the ignorance of law by an individual for alleged state benefits. This obligation is, moreover, broader, since it concerns not only the "state-party" relationship, but also the situation where, due to ignorance of the law, one of the parties to the proceedings could suffer damage to the benefit of another party ${ }^{13}$.

\section{The subjective scope of the principle of informing parties}

The subjective scope of the information principle concerns two groups of entities. On the one hand, these are entities obliged to provide information, and

11 Judgment of the Appellate Court in Szczecin - III Division of Labor and Social Insurance of 9 July 2014. - III AUa 1166/13 - Legalis no. 1231621

12 TARAS, Wojciech. Gloss to the judgment of the Supreme Court of 23 July 1992, III ARN 40/92 Teza 1, PiP glosa 1993/3 / 110-114-LEX

13 ADAMIAK, Barbara. Commentary on Article 9 CAP, [in:] (ed.) B. Adamiak, J. Borkowski, Code of Administrative Procedure. Comment. Ed. 15, Warsaw 2017, Legal status: 27. 06.2017. - Legalis 
on the other hand, they are entities entitled to obtain information. The entities obliged to provide information are public administration bodies and authorized entities of the parties to administrative proceedings.

De lege lata public administration bodies are obliged to properly and comprehensively inform the parties about the factual and legal circumstances. The authorities ensure that the parties and other persons participating in the proceedings do not suffer any damage and provide them with explanations and guidance for this purpose.

The authorities obliged to provide information in the light of Article 9 of the CAP are: a public administration body competent to issue an administrative decision; a public administration body that is obliged to provide legal assistance under Article 52 CAP; a public administration body that issued a decision at first instance, obliged to conduct an additional proceeding to supplement materials and evidence in appeal proceedings; an authority obliged to take a position in the mode of procedure $106 \mathrm{CAP}$, as well as any other public administration body in the scope, which is limited to information about the authority competent for substantive consideration of the administrative case ${ }^{14}$.

The page is authorized. It should be noted that public office is obliged to provide information to the party. The passivity of the authority in this respect is a violation of the law ${ }^{15}$.

This obligation applies directly to the partie, parties to the administrative proceedings. It means that the administrative authority is obliged to provide information about the factual and legal circumstances that may affect the determination of the rights and obligations of the party in a comprehensive and appropriate manner. The wording of the first sentence of Article 9 may raise the question whether this obligation applies to entities with the rights of the parties involved in the administrative procedure. It should be assumed that this provision also applies to entities with the rights of the parties participating in the administrative proceedings. The arguments for the thesis put forward are the following: 1) the procedural nature of the rights creating the parties' rights, and this is the right to receive information from the administrative authority, 2) the subject of information, because it is about factual and legal circumstances that may affect the determination of rights and responsibilities of the party to the proceedings ${ }^{16}$.

14 KNYSIAK-MOLCZYK, Hanna. Commentary on Article 9 CAP, [in:] (ed.) H. KnysiakMolczyk, Code of Administrative Procedure. Commentary, Wyd. Wolters Kluwer, Warsaw 2015, p. 83

15 ADAMIAK, Barbara. Commentary on Article 9 CAP, [in:] B. Adamiak, J. Borkowski, Code of Administrative Procedure. Comment. Ed. 15, Warsaw 2017, Legal status: 2017.06.27 Legalis

16 ŁASZCZYCA, Grzegorz. Commentary on Article 9 KPA, [in:], G. Łaszczyca, C. Martysz, A. Matan, Code of Administrative Procedure, Commentary on art. 1-103, Volume I, Edi- 
In a situation where a party has appointed a representative in an administrative proceeding, the authority should provide him with information and can not omit him in the course of proceedings ${ }^{17}$.

\section{Guarantees for the implementation of the principle of informing parties}

The guarantee of implementation of the principle of informing parties to administrative proceedings are, in particular, the institutions for justifying administrative decisions and instructions.

The provisions of CAP repeatedly impose on public administration authorities the obligation to include instructions, for example: instruction on the consequences of non-compliance (Article $54 \$ 1$ point $6 \mathrm{CAP}$ ), instruction on legal consequences of not reporting deficiencies in the statutory period (Article $64 \$ 2$ CAP), instruction on the legal consequences of the expiry of the three-year period from the date of suspension of the proceedings at the party's request (Article $101 \$ 2$ of the CAP), instruction on admissibility and the procedure of bringing legal remedies from the administrative decision (article $107 \$ 1$ and next) and instruction on admissibility and the procedure of bringing legal remedies from provisions (article $124 \$ 1$ and article $125 \$ 3$ of the CAP).

The consequence of the principle of information referred to in Article 9 of the CAP is also Article 112 of the Code of Administrative Procedure indicating that "Incorrect instruction in the decision on the right of appeal or the consequences of renouncing an appeal or filing a court of law or a complaint to an administrative court can not harm a party who complied with this instruction".

It is worth mentioning here the judgment of the Provincial Administrative Court of October 26, 2017, which states that „If the decision of the first instance authority is defective, the decision of the second instance body also grossly violates the same provisions and the provision of Article $138 \$ 1$ point 1 CAP and should be eliminated from legal transactions. However, the fact that the decision of the second instance authority was not indicated in the application for annulment does not prejudge the groundlessness of the nullity proceedings for reasons of object. The appeal body, which received the application for annulment of the decision of the first instance body, disregarding the decision of the second instance authority, following the principle of the rule of law expressed in Article 7 of the CAP, and bearing in mind the principles of Articles 8 and 9 of the CAP, should include invalidity proceedings decisions of both instances. Alternatively, he could ask the applicant to clarify whether the application also concerns the decision of the second instance authority"18.

tion LEX a Wolters Kluwer business, Warsaw 2010, p. 131

17 WOJCIECHOWSKA, Karolina. Commentary on Article 9 CAP, [in:] (ed.) M. Wierzbowski, R. Hauser, Code of Administrative Procedure. Commentary, Warsaw 2014, Legal status: 2013.02.27 - Legalis

18 Judgment of the Provincial Administrative Court in Szczecin of October 26, 2017 - II SA 


\section{Requests and postulates}

Violation of the principle of providing information may be manifested in three forms: first, refusal to provide information in general; secondly, providing incomplete information, which is limited to selected legal and factual circumstances only; thirdly, provide incorrect information. In the above-mentioned situations, a breach of the principle must result from the act or omission of a public administration body ${ }^{19}$.

Violation of the principle of informing a party to proceedings may consist in omitting the silence of certain important elements of the legal or factual status of the case. Although the provisions of the Code of Administrative Procedure do not explicitly provide for sanctions for violation of the information rule, the case law assumes that: „The obligation to inform and explain to the parties by the body conducting the proceedings the entire factual and legal circumstances of the pending case (...) should be understood as broadly as it is only possible. A proven breach of this obligation should be understood as a sufficient basis to repeal the decision" 20 . A proven breach of this obligation should be understood as a sufficient basis to set aside the contested decision ${ }^{21}$.

According to the verdict of the Provincial Administrative Court of 20 February 2009, violation of the principle of informing citizens may constitute an independent and sufficient reason for repealing the decision, even if it is consistent with substantive law ${ }^{22}$.

Violation of the information obligation by the public administration body may be considered as an objective element of guilt or unlawfulness. It is one of the premises of tort liability. Therefore, if the entity entitled to obtain information has suffered damage as a result of a breach of the information obligation

/ Sz 940/17 - Legalis no. 1694139

19 ŁASZCZYCA, Grzegorz. Commentary on Article 9 CAP, [in:], G. Łaszczyca, C. Martysz, A. Matan, Code of Administrative Procedure..., p. 134; See. Judgment of the Voivodship Administrative Court in Warsaw of 9 July 2014, V SA / Wa 593/14 - LEX No. 1066368 „The right to information (Article $9 \mathrm{CAP}$ ) is not unlimited, as it is limited only to rights and obligations subject to administrative proceedings. The body has no obligation to inform about possible hypothetical situations that may occur in the future. Violation of this principle is manifested in: a) refusal to provide information to the party, or b) improper information provided, by providing unclear or incorrect information or providing non-exhaustive information, i.e. one that omits the factual or legal circumstances that are relevant to the case ( ...)".

20 Judgment of the Provincial Administrative Court in Poznań of October 28, 2009, IV SA / Po 476/09 - Legalis No. 343819

21 See: Judgment of the Supreme Administrative Court (N) of February 1, 2011, II OSK 230/10 - Legalis No. 348208

22 Judgment of the Provincial Administrative Court in Lublin of February 20, 2009, II SA / Lu 623/08 - Legalis No. 244909 
by the administrative authority, it can claim damages in proceedings before a common court ${ }^{23}$.

On the other hand, in a special way, the violation of the provisions establishing procedural institutions guaranteeing „the implementation of the information principle may take the form of qualified violations of law that constitute grounds for resuming administrative proceedings" ${ }^{24}$, referred to in art. $145 \$ 1$ points 4 and 5 of the CAP.

It should be noted that the violation of the principle of informing the party to the proceedings manifests itself in specific procedural institutions implementing this principle, and may assume various forms. In particular, they may constitute grounds for repealing the contested decision in whole or in part due to a breach of law giving rise to the resumption of administrative proceedings.

Based on the analysis, it should be assumed that the damage resulting from lack of information should be repaired in further proceedings, for example: by admitting evidence, allowing additional comments in the case, restoring the deadline, etc. What is more, you can postulate to regulate the legal consequences in CAP violation of the party's right to information.

\section{References}

ADAMIAK, Barbara. Commentary on Article 9 CAP, [in:] (ed.) B. Adamiak, J. Borkowski, Code of Administrative Procedure. Comment. Ed. 15, Warsaw 2017, Legal status: 27. 06.2017. - Legalis.

KNYSIAK-MOLCZYK, Hanna. Commentary on Article 9 CAP, [in:] (ed.) H. Knysiak-Molczyk, Code of Administrative Procedure. Commentary, Wyd. Wolters Kluwer, Warsaw 2015.

ŁASZCZYCA, Grzegorz. Commentary on Article 9 KPA, [in:], G. Łaszczyca, C. Martysz, A. Matan, Code of Administrative Procedure, Commentary on art. 1-103, Volume I, Edition LEX a Wolters Kluwer business, Warsaw 2010.

TARAS, Wojciech. Gloss to the judgment of the Supreme Court of 23 July 1992, III ARN 40/92 Teza 1, PiP glosa 1993/3 / 110-114-LEX

WOJCIECHOWSKA, Karolina. Commentary on Article 9 CAP, [in:] (ed.) M. Wierzbowski, R. Hauser, Code of Administrative Procedure. Commentary, Warsaw 2014, Legal status: 2013.02.27 - Legalis.

23 KNYSIAK-MOLCZYK, Hanna, Commentary on Article 9 CAP, [in:] (ed.) H. KnysiakMolczyk, Code of Administrative Procedure..., p. 89

24 Ibidem, p. 89 